DOI: 10.1515/auseur-2016-0024

\title{
The Interoperability between the Public and Private Sectors in Light of Adult Education. Supplements to the Planned Downsizing in the Public Sector
}

\author{
Csilla MEGYESI \\ Veritas Research Institute, Budapest \\ csilla.megyesi@veritas.gov.hu
}

\begin{abstract}
The current study is a result of the Hungarian government's aspiration to cut bureaucracy and increase public administration's efficiency, thus impacting personnel and reorganizing the labour market. The publicsector headcount reduction is being justified in terms of Hungary's inadequate private-/public-sector employment ratio. This reorganization can come to fruition only via the development of intellectual capital and a well-designed system for retraining and further education. In cases of retraining and further education offered by the state, we must be wary of generational differences and possible motivations, while also keeping in mind the influence education can have on the market, society, and the individual. Our research has shown that the demand for a given type of instruction is also influenced by the generational differences among those who wish to learn. Overall, our respondents showed an interest in learning.
\end{abstract}

Keywords: public sector, private sector, employment, knowledge, education, retraining, bureaucracy

\section{Introductory Thoughts}

2016 began with a significant announcement for the Hungarian public administration staff: on January $21^{\text {st }}$, the Minister of the Prime Minister's Office announced that the government planned the restructuring or elimination of more than seventy state/national background institutional budgetary entities. ${ }^{1}$

1 Mandiner, Durva közigazgatási átszervezésre készül a kormány, January 21 ${ }^{\text {st }}$, 2016. Available at: http://mandiner.hu/cikk/20160121_durva_kozigazgatasi_atszervezesre_keszul_a_kormany (2016/03/21).

Quote from the article: 'János Lázár said that in the next few days negotiations would begin between the Ministry of the Prime Minister's Office and the various portfolios on how to return the background institutions and budgetary entities to the portfolios and eliminate outsourcing, 
Since that initial announcement, the figure of 100-150 thousand dismissed public sector workers by the end of the term has been made known, which by all means will play a significant role in the reorganization of the Hungarian labour market. Although the announcement itself came as a surprise, there had been earlier indications. In 2015, the government published a document titled Public Administration and Public Services Development Strategy 2014-2020, ${ }^{2}$ which made reference to streamlining bureaucracy, albeit in a different context. Earlier, the government had already set the goal of creating a strong, service-oriented and customer-friendly state in an attempt to elevate Hungarian public administration efficiency to European and international levels. The 2015 development strategy only confirmed this stance. One of the ways to achieve it is by reducing bureaucracy, which, on the one hand, means simplifying both the regulatory environment and client administration, thereby reducing cost and increasing transparency, and, on the other hand - and more importantly from the perspective of the current study - , modernizing the management of human resources. ${ }^{3}$

Since January, the government has been working on a plan to help those who will be negatively impacted find employment again, while at the same time confirming the launch of the Karrier Híd (Carrier Bridge) programme, which will spur migration from the public to the private sector through retraining and other means. ${ }^{4}$

In March 2016, we conducted a questionnaire survey in order to develop a broader picture of the interoperability between the public and private sectors, paying particular attention to the impact adult education had on employment mobility. In the current study, we wish to show this interrelationship, using our findings from the questionnaire, and to outline the possible outcomes of the impact and intercession of (re)training, as we believe that during the labour market reorganization timeframe (resulting from the planned bureaucratic downsizing) the examination of certain matters will indeed be relevant. Thus, we will review the scientific and policy aspects influencing the subject. The professional literature has extensively covered these aspects, and when considered on an individual basis each one could qualify as a research topic unto itself. That being the case, the goal of the current paper is only to identify and analyse the associated problems; no detailed solutions will be forthcoming.

thereby running the system more simply, cost-effectively, and expeditiously. He indicated that fifty thousand people are currently working in these institutions and organizations.'

2 Közigazgatásésközszolgáltatás-fejlesztésistratégia 2014-2020. Availableat:http://www.kormany. hu/download/8/42/40000/K\%C3\%B6zigazgat\%C3\%A1s_feljeszt\%C3\%A9si_strat\%C3 \%A9gia_.pdf (2016/03/21).

3 'The goal of the Strategy is complex: reducing gross procedural deadlines and resources used, including both human and financial resources. That is, we cannot allow shortened deadlines to lead to an increase in allocated resources. Rather we must achieve real growth in efficiency in public administration.' Közigazgatás és közszolgáltatás-fejlesztési stratégia 2014-2020, pp. 32.

4 See: http://www.vg.hu/gazdasag/hitel-a-karrier-hidban-464676. Hitel a Karrier Hídban, January $28^{\text {th }}, 2016(2016 / 03 / 21)$. 
When defining the issue, we will have to deal with such questions as what knowledge is. Drawing conclusions about adult education will require us to review the professional literature pertaining to andragogy. Information, knowledge (both explicit and tacit), and the competencies essential from a labour market perspective all make up part of the conceptual foundation of the issue. Moreover, it raises the question: If the focus is on labour market mobility, then what are the most important lessons and competencies for the state, the market, and the individuals making up the market? Utilizing andragogical insights and the findings of both European and domestic surveys, we must review the adult population's attitudes towards education and where Hungary stands in making the European goal of lifelong learning a reality. The above concerns will surely be raised during the public sector's reorganization.

Adult education (whether within the framework of school or outside of it, formal or informal, or retraining or further education) has never been more indispensable than today. Questions open to debate, however, are what methods should be used in the transference of education and what kind of training/ development is necessary. Another unresolved question is what knowledge is required nowadays by the market players that hire workers and by the state, which takes complicated economic and social goals into consideration. The value of knowledge is relative and depends on the circumstances in which it is used. Knowledge is both a destination and a journey (Szabóné Fenyvesi 2006: 246247). So, if we are to examine the interoperability between the public and private sectors, then we must research where the interests of the market and the state overlap. We must pay special attention to the prevailing trends and objectives of public administration and to economic and labour market indicators.

Three different but nonetheless interrelated adult educational hypotheses have guided us:

- that adult education boosts the possibility for public/private sector career advancement and mobility;

- that public/private sector mobility as a result of adult education is an overall economic, social, and personal good;

- that public/private sector mobility as a result of adult education reduces unemployment.

Based on both our review of the professional literature and our own survey, we believe that adult education indeed increases mobility as it is in accordance with the development of expected labour market skills and competencies. Mobility certainly serves economic purposes as it drives savings at the state level and increased tax revenues, which lead to more competitive public administration. It also serves social purposes as, on the one hand, a labour market mobile employee does not depend on the state and, on the other hand, the state may therefore make budgetary assumptions of fewer pay-outs of unemployment benefits in the 
long term. Mobility may serve the personal good too as long as we view personal development and financial security as such. Mobility also reduces unemployment.

\section{The Basic Data of the Questionnaire Examining Interoperability (March 2016)}

We conducted the survey in March 2016, using a self-reporting questionnaire. Of the almost 360 responses, males made up $48.9 \%$, females $51.1 \%$. By age category, $10.3 \%$ was under 25 years of age; $27.7 \%$ between the ages of 25 and 40 , which is to say belonging mainly to Generation Y; $31.6 \%$ between the ages of 40 and 55; $23.2 \%$ between 55 and 65 .

The breakdown by educational attainment was the following: $6.1 \%$ lacked a general certificate of secondary education (graduation/érettségi); $26.6 \%$ had a general certificate of secondary education and an intermediate- to advanced-level trade certificate; $67.3 \%$ had either a college or university degree.

The breakdown by employment was the following: a plurality of respondents $(44.7 \%)$ were white-collar employees, while $14 \%$ were working in some other field of non-manual work. $17.3 \%$ were in leadership positions and $16.5 \%$ were entrepreneurs. The vast majority $(64.8 \%)$ had more than fifteen years of work experience. At the time of the survey, $45.5 \%$ worked in the public sector, $31.3 \%$ in the private sector, $8.7 \%$ simultaneously in both, and $5.3 \%$ in the civil sector. The rest of the respondents were inactive (either retired, attending school, involuntarily unemployed, on maternity leave, etc.).

A high percentage of respondents (41.9\%) had worked or were currently working in both sectors, thus disposing of an intimate familiarity of both sectors.

Have you ever changed jobs, moving from the public sector to the private sector or vice versa, from the private sector to the public sector?

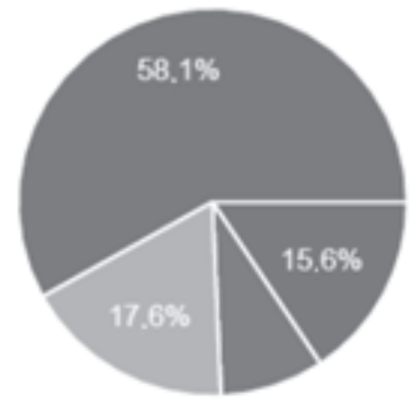

\begin{tabular}{lcc}
\hline $\begin{array}{l}\text { Yes, I moved from the private } \\
\text { sector to the public sector. }\end{array}$ & 56 & $15.6 \%$ \\
$\begin{array}{l}\text { Yes, I moved from the public } \\
\text { sector to the private sector. }\end{array}$ & 31 & $8.7 \%$ \\
$\begin{array}{l}\text { Yes, I have moved from one } \\
\text { sector to the other several times. }\end{array}$ & 63 & $17.6 \%$ \\
\hline No. & 208 & $58.1 \%$ \\
\hline
\end{tabular}

Source: Own survey, March 2016

Diagram 1. Respondents' relationship with the public and private sectors 


\section{Knowledge and Competencies in the $21^{\text {st }}$ Century}

In our age, dwindling resources are becoming an increasing concern; simultaneously renewable energy resources are receiving increasing attention. Researchers believe that mankind's capacity for knowledge is similarly inexhaustible and deserves greater attention in the future. Despite its appearance of inexhaustibility, it should nonetheless be managed with care. 'An increasing number of studies shows that the only companies and economies capable of unlocking the inherent power of knowledge are the ones that properly manage it' (Szabóné Fenyvesi 2006: 243). In the history of humankind, the process by which and especially to what extent science and technology transform society, culture, the economy, and institutions has been unprecedented, giving rise to challenges that humankind may not be prepared to face. It would seem, however, that knowledge (more precisely, the ability and willingness to learn) presents the best solution if we wish to avoid being caught off-guard. Our mind-set towards education is being recast by the paradigm of lifelong learning.

What is the knowledge that today's active and responsible citizen/employee should possess? It is common to refer to our era as the Information Age. At the same time, however, one can sense that in the torrent of information knowledge has been relegated to a lesser role. At the very bottom of the hierarchy of knowledge is datum, which is nothing more than an element of information. That element becomes information only if it has meaning for the subject. Knowledge occupies a higher position in the hierarchy. Knowledge is 'interpreted and subjective information that can be activated and productively used. It is information that bears meaning and has the capacity to be applied and utilized' (Szabóné Fenyvesi 2006: 244). In simpler terms, it means that the human mind uses data to create information and knowledge. Knowledge belongs uniquely to who has possession of it.

The concept of knowledge can be further specified, which a famous researcher of Hungarian descent, Michael Polanyi, was the first to do. He divided knowledge into two types: explicit and tacit. Explicit knowledge is knowledge that can be expressed in numbers and words, while tacit knowledge is inferred knowledge that is entirely unique and difficult to explain (formalize). Premonitions, suspicions, and intuition are all classified as tacit knowledge and are deeply rooted in our actions and experiences. Tacit knowledge has a technical or practical component that translates into skills and proficiency, and a cognitive dimension composed of faith, ideas, values, schemata, and mental models (Szabóné Fenyvesi 2006: 245-246). This type of knowledge has as much to do with being successful as professional knowledge does.

More than $90 \%$ of respondents in our survey believed that their tacit knowledge expanded greatly or at least sufficiently during their working years. 
It has been said that an employee not only gains professional experience through his work but learns how to work. 'Learning to work' is a passive, personal knowledge that an employee acquires through practice, and it is as important as professional knowledge. How much has your passive, personal knowledge developed during your working career?

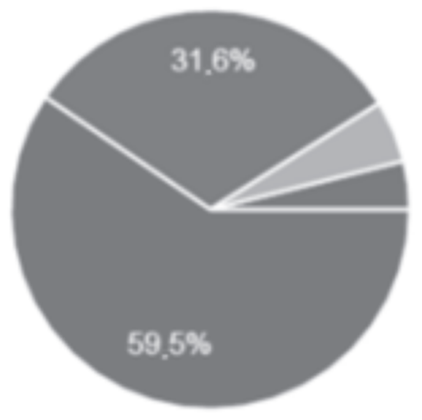

\begin{tabular}{lcc}
\hline Greatly & 213 & $59.5 \%$ \\
\hline Sufficiently & 113 & $31.6 \%$ \\
\hline Little & 18 & $5 \%$ \\
\hline Not at all & 14 & $3.9 \%$ \\
\hline
\end{tabular}

Diagram 2. Tacit knowledge

Source: Own survey, March, 2016

A competitive economy, sustainable growth, improving employment numbers, better and more job opportunities, and the attainment of social cohesion all depend on whether European society is capable of adapting its knowledge and competencies on a regular basis. In March 2000, the leaders of the European Union met in Lisbon to address the above issues. Afterwards, this action and developmental plan would be referred to as the Lisbon Strategy, the goal of which was to make the European Union by 2010 the most competitive and dynamic knowledge-based economy in the world, capable of sustainable economic growth with more and better jobs and greater social cohesion. ${ }^{5}$ Obviously, the global financial crisis of 2008 up-ended these plans. In 2010, the European Commission proposed a new programme named Europe 2020, ${ }^{6}$ which was considered an extension of the Lisbon Strategy. According to the new document, one of the three pillars of economic growth was smart growth, which indicated the formation of a knowledge- and innovation-based economy.

The pan-European strategies devised to bring forth a knowledge-based society focusing all attention on adult education, particularly on developing a successful European practice of lifelong learning. Since the beginning of the 2000's, a framework has been developed, going through several phases, which encompasses key competencies to spur learning over an entire lifetime. ${ }^{7}$ On the

$5 \quad$ The Lisbon Strategy 2000-2010. An Analysis and Evaluation of the Methods Used and Results Achieved. Available at: http://www.europarl.europa.eu/document/activities/cont/201107/2011 0718ATT24270/20110718ATT 24270 EN.pdf (2013/03/21).

6 Europe 2020: Europe's Growth Strategy: Growing to a Sustainable and Job-Rich Future. http://ec.europa.eu/europe2020/pdf/europe_2020_explained.pdf (2013/03/21).

7 A Hungarian-language article is available at the Hungarian Institute for Educational Research 
one hand, the framework determines what we may refer to as key competencies and, on the other hand, it reveals their significance in driving personal success, be it at the workplace or any other area of life.

Key competencies are the combination of knowledge, skills, and attitudes necessary for personal fulfilment and development, social inclusion, and employment. Key competencies should be acquired during compulsory education and training. These competencies will form the basis for further learning across a lifetime. ...key competencies are transferable, which means that they may be applied in numerous different situations and contexts. Additionally, key competencies are multifunctional, which means that they may be used to reach different goals and solve different problems and tasks. They are the prerequisites to personal, work, and future educational success. ${ }^{8}$

The European Union framework has identified eight basic competencies (see the Appendix). These competencies should be learned in elementary school and further developed over a lifetime. This reference framework also applies to disadvantaged groups, who shall learn them in remedial instruction. These same competencies may also be applied in high-level further development/training to individuals active in the labour market. ${ }^{9}$

There is an obvious interrelation between successful work and the key competencies. A Hungarian Central Statistical Office study reports the following: The European statistical system (Eurostat) closely monitors businesses to see which competencies' development they are supporting. From the report: 'In the Continuing Vocational Training Survey (CVTS), participants were asked which skills and competencies among those listed were important. All of the skills and competencies deemed important in terms of work could be classified as a key competency or as being partially akin to one'. ${ }^{10}$

According to data gathered on Hungarian businesses in 2010, most of the businesses (irrespective of size) reported that technical, practical, and jobspecific skills were the most important. More than $40 \%$ reported that teamwork was also important; likewise, more than $40 \%$ reported problem-solving skills as such. Foreign language knowledge and IT know-how were also considered to be sought-after skills, while typically only the larger businesses considered leadership skills to be important. ${ }^{11}$

and Development website: Az egész életen át tartó tanuláshoz szükséges kulcskompetenciák. http://ofi.hu/tudastar/nemzetkozi-kitekintes/egesz-eleten-at-tarto (2013/03/21)

8 http://ofi.hu/tudastar/nemzetkozi-kitekintes/egesz-eleten-at-tarto (2013/03/21)

9 http://ofi.hu/tudastar/nemzetkozi-kitekintes/egesz-eleten-at-tarto (2013/03/21)

10 The Hungarian Central Statistical Office: Felnôttoktatás, felnőttképzés, March 2014. p. 20. https://www.ksh.hu/docs/hun/xftp/stattukor/felnottoktatas13.pdf (2013/03/22)

https://www.ksh.hu/docs/hun/xftp/stattukor/felnottoktatas13.pdf (2013/03/22) 
Employees recognize the perceived or real needs of the labour market, which our survey's answers also reflected. Professional training was the most popular, while demand for foreign language instruction and computer training were also high.

Currently, for which type of training would you have the most need? Which one would you consider as the most useful?

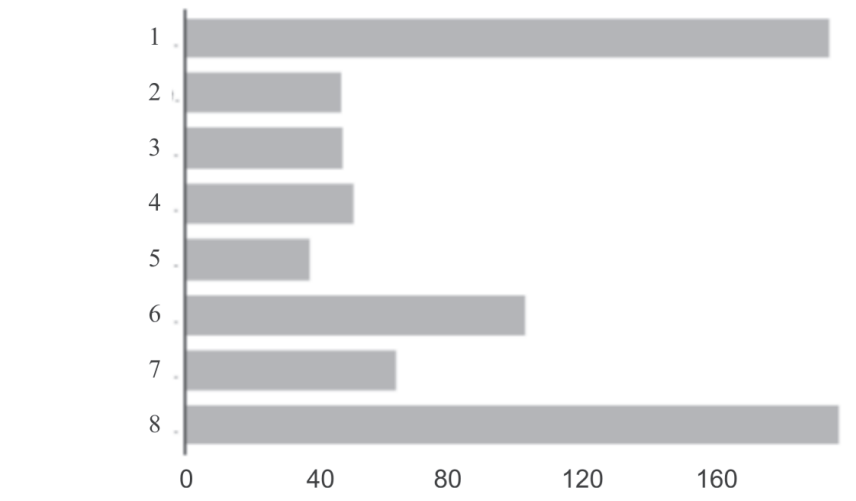

\begin{tabular}{clcc}
\hline 1. & Professional (further training in one's current field) & 195 & $54.5 \%$ \\
\hline 2. & Legal & 47 & $13.1 \%$ \\
\hline 3. & Economics/Finance & 48 & $13.4 \%$ \\
\hline 4. & Marketing & 51 & $14.2 \%$ \\
\hline 5. & Human Resources Management & 38 & $10.6 \%$ \\
\hline 6. & IT & 103 & $28.8 \%$ \\
\hline 7. & Communications & 64 & $17.9 \%$ \\
\hline 8. & Foreign language & 198 & $55.3 \%$ \\
\hline
\end{tabular}

Source: Own survey, March, 2016

Diagram 3. Most useful trainings

The compilation of data (on a like-for-like basis and employing a uniform methodology) related to adult education/adult training was begun in 2011/2012 in the member states of the European Union. Within this framework, Hungary began collecting data in Q1 2012, the findings of which the Hungarian Central Statistical Office published in March 2014. In 2011, 27.2\% of Hungarians between the ages of 25 and 64 took part in some form of organized instruction or training. Broken down by sex, women had taken part in a slightly higher proportion $(28.2 \%$ vs $26.2 \%)$. According to the survey, there was a strong correlation between economic engagement and participation in learning: '...those engaged in the economy including those who are employed - learn in much higher numbers than those who do not. More than a third of employed Hungarians participated in some form of organized learning, including nearly $40 \%$ of women and less than $33 \%$ of men. ${ }^{12}$

12 https://www.ksh.hu/docs/hun/xftp/stattukor/felnottoktatas13.pdf (2013/03/22). 
The biggest gap in terms of participation in adult learning can be seen on the basis of highest educational level attained. It is worthwhile to take a closer look at these data if we wish to learn how and why it is possible for an individual to fall outside the influence of education, especially when considering training (instruction), whose purpose is to lower unemployment. What are the attitudes (or lack thereof) characteristic of someone unable to seize educational opportunities both within the school system and outside of it? ${ }^{13}$ Presumably, the 'Learning to Learn' key competency plays a major role in explaining why the unemployable cannot effectively compete against the followers of lifelong learning in either the labour market or on a social level. According to the 2014 Hungarian Central Statistical Office report, '.... while only $10 \%$ of individuals with at most a primary school education participated in some form of institutionalized learning, the percentage rises to $30 \%$ among those with a general certificate of secondary education and to $50 \%$ among those with a college or university education'. ${ }^{14}$

The same trend is observable in the forms of training (instruction) outside of the school system. One quarter of the population between the ages of 25 and 64 took part in such training and, with regards to educational attainment, while $47 \%$ of those with higher educational attainment participated, the number drops to approximately $10 \%$ for those with at most a primary school education. ${ }^{15}$ The risk is high for individuals who choose not to participate in learning: Not only are they locked out of the labour market but the opportunities offered in our rapidlychanging $21^{\text {st }}$-century society may potentially be beyond their grasp as well, all while their lack of social integration manifests as a permanent and difficult-tosolve challenge for the state and society.

Thus, everyone could benefit from an improved understanding of certain key competencies, the means of which would be provided within the framework of social uplift for those who have been left behind, while the adjustments of the ever-changing needs of the labour market would help those citizens already participating in the labour market.

13 The 2009 study on adult education by the State Audit Office of Hungary makes note of the following when presenting the flaws and shortcomings of the Hungarian adult educational system: 'The people who have the greatest need to develop their competencies, those at a disadvantage on the labour market, participate in the lowest numbers in the training. The participation rate of Hungarians with at most an $8^{\text {th }}$-grade education is 25 percent, versus a 42-percent average for jobseekers'. Jánossy, Dániel-Dr Kiss, Daisy-Dr Pulay, Gyula: A felnôttképzési rendszerek hatékonysága nemzetközi összehasonlításban. The State Audit Office of Hungary, 2009. pp. 7-8. https://www. asz.hu/storage/files/files/Szakmai\%20kutat\%C3\%A1s/2009/t312.pdf (2016/03/22). Ibid.

15 Ibid. p. 16, $3^{\text {rd }}$ diagram. 


\section{Some Traits of the Hungarian Private and Public Sectors in the Years Following the System Changeover}

If the plans to cut government bureaucracy come to fruition, then the redundant public sector employees will inundate the private sector, raising problems related to interoperability between the two sectors. A commonality among studies is the constant comparing of the public and private sectors to each other, for best practices (irrespective of which sector they originate from) are an important aspect in public administration policy debates. An article published in 2014 compared and contrasted human resources management in both the public and private sectors on the international level, paying special attention to administrative trends and region affiliation in the examined countries. From the introduction of the article: 'The public/private sectors' debate is taking place on multiple levels: in the trade press as much as on the floor of legislatures and other areas of social life. The issues encompass the traditional problems associated with privatization such as questions about healthcare coverage and other services (utilities, pension plans, etc.) belonging in private hands or to the public in general' (Poór-Karoliny-Musztiné Bátfai-Pótó-Farkas 2014: 127). The surveys do evince that the public administration tendencies that characterized the years preceding the System Changeover from communism had left their mark, for even as late as 2004-2005 the human resources management teams in the public sectors of the Eastern and Central European countries had more in common with each other than with the management teams of those countries following the New Public Management (NPM) philosophy. By the time of the 2008-2010 surveys, however, the picture had changed, with Eastern and Central Europe moving into the direction of adopting NPM practices (Poór-Karoliny-Musztiné Bátfai-PótóFarkas 2014: 144).

Human resources management had earlier held three beliefs: 1) that public administration was a specialized field requiring skills that could not be gained from the outside or from other fields of the labour market; 2) that these skills could not be utilized outside of public administration; 3) that therefore interoperability between the public and private sectors was not characteristic (Gellén 2013: 37). As a result, none of these were valid any longer. Weber's Model for Bureaucracy had had deep roots in Hungarian society, but following the System Changeover, the introduction of the public management approach was attempted in several areas, which may have triggered interoperability between the sectors. Interoperability was further strengthened by the fact that following the System Changeover both healthcare services and education expanded into the private sector, thus operating within the framework of public services and outside them. Privately- 
run hospitals and clinics appeared, as well as private universities, foundation schools, and nursery schools. The majority of the doctors, pharmacists, educators, and instructors working in these establishments had left the public sector behind, finding contentment in the private sector.

The survey results in the 2014 study shows that the similarities and differences in public and private sector human resources management practices are variable across countries, regions, and time. Currently in our region, the so-called crossvergence is trending. That is, both the similarities and differences equally prevail in bi-sector HR practice (Poór-Karoliny-Musztiné Bátfai-Pótó-Farkas 2014: 131-141). This supports our earlier supposition that interoperability between the two sectors could be successful given an adult education system capable of providing relevant and up-to-date knowledge. The answers provided by our own survey's respondents further support this premise.

More than $50 \%$ of respondents believed that in a given field any work-related public-private sector divergence that may arise in everyday practice could be overcome with the right training.

Within a given field (for example, management), there are everyday differences between the private sector and the public sector. These may result from the peculiarities of each sector. Do you believe these sector-specific differences can be bridged with organized training for adults?

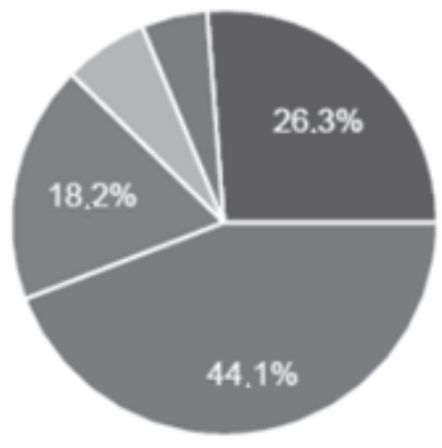

\begin{tabular}{lcc}
\hline Yes, for the most part. & 158 & $44.1 \%$ \\
\hline No, for the most part. & 65 & $18.2 \%$ \\
\hline Yes, completely. & 23 & $6.4 \%$ \\
\hline Not completely. & 18 & $5 \%$ \\
\hline I do not know. & 94 & $26.3 \%$ \\
\hline
\end{tabular}

Diagram 4. Sector-specific differences

Interoperability is further strengthened by the fact that there is currently a large number of public administration employees with non-public administration educational backgrounds. In practice, their vocational/educational backgrounds are varied indeed. (Let us remember that despite their very different backgrounds, a cook working as a public sector employee in either a school or a hospital and a teacher or architect working as a public sector employee or civil servant at a ministry, a local government council, or a background institution are both 
classified as state employees.) Furthermore, we must note that there are professions whose numbers are found equally in either sector. The people qualified for these roles can easily find work in either sector. For example, many lawyers are either employed by law firms or run their own, while just as many may work as jurists, prosecutors, or legal advisors in public administration. IT specialists are in a similar situation. Although demand for their work more typically comes from the private sector, many of them have found jobs in public administration or as civil servants. We may observe that those who work in operations - be it as IT specialists, machinists, or architects - are able to work in their fields in either sector. Interoperability is plausible for them, with no real need for retraining or further education. Training is typically necessary only if the given position is an administrative or leadership role because in that case in order to pass the public administration basic and department exams the employee must become familiar with administrative basics. What public institution the given employee works for, however, is irrelevant for professional and personal aptitude (the acquired and necessary experience and knowledge in public administration) must be present at all stages of the progression.

\section{Public-Sector Headcount}

Following the System Changeover, the number of government officials, civil servants, public servants, individuals employed in professional services, individuals classified as employed per the Labour Code, individuals assigned public administrative tasks, and state-related corporate sector workers all increased. In Hungary, the role and importance of public administration grew even within the public sector; not only was the proportion of workers in the sector above the regional average but it also compared poorly to the other European countries. ${ }^{16}$

16 Kézdi, Gábor: Foglalkoztatás és keresetek a közszférában. In: Társadalmi riport, 1998. Kolosi, Tamás-Tóth, István György-Vukovich, György (eds). Budapest: TÁRKI, pp. 143-170. (TÁRKI’s research analysed the circumstances of Hungarian public-sector workers from the 1970s to the end of the 1990s.) The article's online version appeared in 2006. Available at: http:// www.tarki.hu/adatbank-h/kutjel/pdf/a868.pdf (2016/03/22): 'When compared to the other former communist countries of Eastern and Central Europe, the percentage of workers in the Hungarian public sector is extremely high: only Slovenia surpasses Hungary's 23\%.' 'The Public administration's role in Hungary is especially significant; not only does the percentage, which is greater than $8 \%$, stand out in the region but it is also considered to be extremely high across the whole of Europe... The picture changes, however, if we make the comparison versus total population instead of total number of workers: Hungary is near the bottom for public sector workers per capita among the transition economies.' These discrepancies are a result of Hungary's lower rates of employment. pp. 146-147. 
In recent years, the number of employees in the public sector has continued to grow. Of the approximately four million Hungarians who are currently working, about one million are employed by the state, posing a serious risk to economic competitiveness. The number of private-sector employees is lower than what would be considered ideal, resulting in lower economic output, lower tax revenue for the state and stunted GDP growth. Reduced economic growth further results in diminished levels of service by the government (in education, healthcare, culture, infrastructure, etc.) and an overall falling standard of living. In January, Nándor Csepreghy, the Minister of State of the Prime Minister's Office, said that with one-tenth of all Hungarians, or one-fourth of all employees, working for the state, it was the government's goal in the long run to copy the Scandinavian Model, whereby only one-tenth of all employees would be composed of public-sector workers. Therefore, within five to ten years, approximately six hundred thousand individuals would move into the private sector, based upon the assumption that the private sector could generate an abundance of new jobs. ${ }^{17}$ In other words, the main concern is the public-vs-private-sector employment ratio, and not the aggregate number of employees. ${ }^{18}$

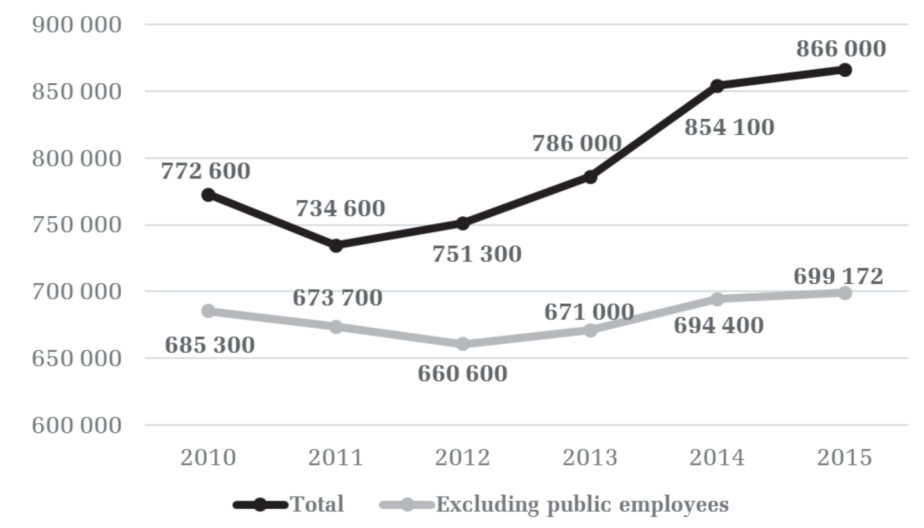

Source: http://www.metropol.hu/itthon/cikk/1405209 (2016/03/22)

Diagram 5. The progression of public-sector employment in recent years

17 Mandiner, Csepreghy: 100-200 ezer közalkalmazottat át lehet terelni a versenyszférába, January $6^{\text {th }}$, 2016. Available at: http://mandiner.hu/cikk/20160105_csepreghy_100_200_ezer_ kozalkalmazottat_at_lehet_terelni_a_versenyszferaba (2016/03/22).

18 András Földiák, President of the Forum for the Co-operation of Trade Unions, said the following about the government's plans: 'When making a comparison to total population, if we exclude public workers from the total number of public service workers, then we can see right away that Hungary is below the European average. The numbers are not unfavourable at all with other comparisons, only when compared to the private-sector percentage. Let me emphasize that the issue is not so much that the number of public-service workers is high, but rather that the number of private-sector workers is low.' Profession.hu, Elbocsátások ellen tiltakoznak a közszférában, January $11^{\text {th }}$, 2016. https://www.profession.hu/cikk_felmondas/20160111/ elbocsatasok-ellen-tiltakoznak-a-kozszferaban/6166\# (2016/03/22). 


\section{Number of Public-Sector Employees}

In the chart below, we can clearly see the steady increase in the number of publicsector employees (including a year-over-year percentage comparison).

Table 1. Civil servants'/public servants' headcount at state institutions State Institutions Total

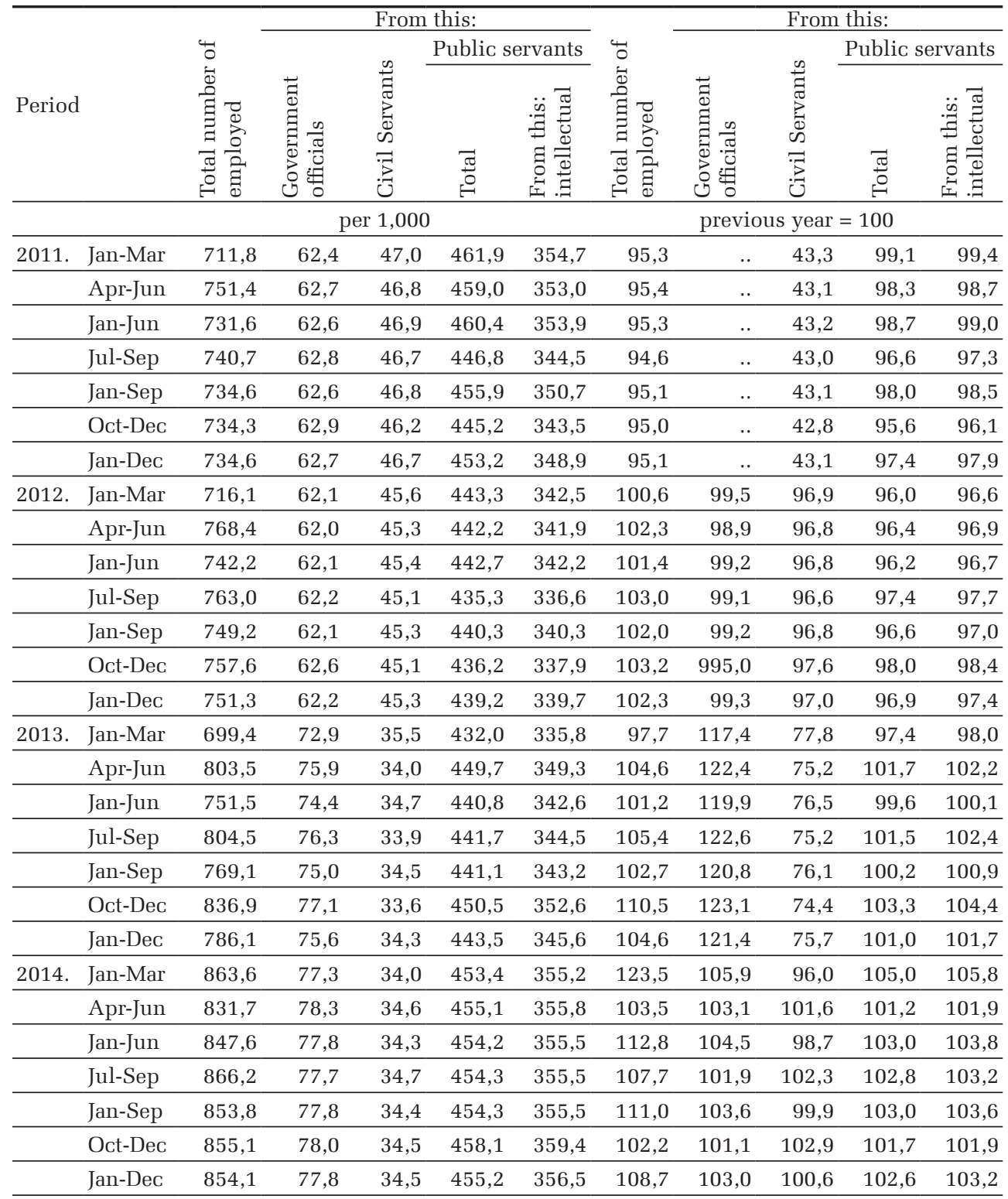




\begin{tabular}{|c|c|c|c|c|c|c|c|c|c|c|c|}
\hline \multirow[b]{3}{*}{ Period } & & \multirow{3}{*}{ 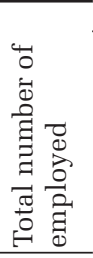 } & \multicolumn{4}{|c|}{ From this: } & \multirow{3}{*}{ 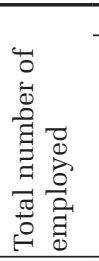 } & \multicolumn{4}{|c|}{ From this: } \\
\hline & & & \multirow[b]{2}{*}{ 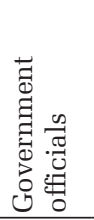 } & \multirow[b]{2}{*}{ 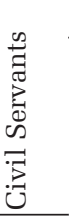 } & \multicolumn{2}{|c|}{ Public servants } & & \multirow[b]{2}{*}{ 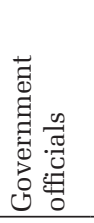 } & \multirow[b]{2}{*}{ 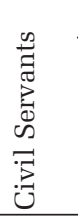 } & \multicolumn{2}{|c|}{ Public servants } \\
\hline & & & & & 氶 & 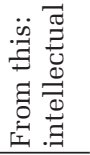 & & & & $\stackrel{\pi}{\frac{\pi}{0}}$ & 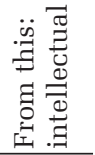 \\
\hline \multirow[t]{7}{*}{2015.} & Jan-Mar & 845,0 & 78,1 & 34,8 & 459,8 & 360,6 & 97,9 & 101,1 & 102,4 & 101,4 & 101,5 \\
\hline & Apr-Jun & 866,6 & 78,5 & 34,9 & 459,5 & 360,2 & 104,2 & 100,2 & 100,9 & 101,0 & 101,2 \\
\hline & Jan-Jun & 855,8 & 78,3 & 34,9 & 459,6 & 360,4 & 101,0 & 100,6 & 101,7 & 101,2 & 101,4 \\
\hline & Jul-Sep & 886,4 & 79,1 & 34,9 & 457,8 & 359,3 & 102,3 & 101,8 & 100,6 & 100,8 & 101,1 \\
\hline & Jan-Sep & 866,0 & 78,6 & 34,9 & 459,0 & 360,0 & 101,4 & 101,0 & 101,3 & 101,1 & 101,3 \\
\hline & Oct-Dec & 874.7 & 79,8 & 33,3 & 458,6 & 360,4 & 102,3 & 102,3 & 96,5 & 100,1 & 100,3 \\
\hline & Jan-Dec & 868.2 & 78,9 & 34,5 & 458,9 & 360,1 & 101,6 & 101,3 & 100,1 & 100,8 & 101,0 \\
\hline \multirow[t]{7}{*}{2016.} & Jan-Mar & 860.6 & 78,0 & 34,3 & 451,9 & 355,7 & 101,8 & 99,9 & 98,4 & 98,3 & 98,6 \\
\hline & Apr-Jun & 884.6 & 77,6 & 34,6 & 451,1 & 354,8 & 102,1 & 98,9 & 99,0 & 98,2 & 98,5 \\
\hline & Jan-Jun & 872.6 & 77,8 & 34,4 & 451,5 & 355,2 & 102,0 & 99,4 & 98,7 & 98,2 & 98,6 \\
\hline & Jul-Sep & 878.5 & 61,0 & 34,5 & 448,9 & 353,5 & 99,1 & 77,1 & 98,8 & 98,1 & 98,4 \\
\hline & Jan-Sep & 874.6 & 72,2 & 34,4 & 450,6 & 354,7 & 101,0 & 91,9 & 98,7 & 98,2 & 98,5 \\
\hline & Oct-Dec & 867.5 & 61,0 & 34,3 & 449,4 & 354,1 & 99,2 & 76,5 & 103,0 & 98,0 & 98,3 \\
\hline & Jan-Dec & 872.8 & 69,4 & 34,4 & 450,3 & 354,5 & 100,5 & 88,0 & 99,8 & 98,1 & 98,4 \\
\hline
\end{tabular}

The government has already turned its attention to the challenges posed by headcount consolidation, as per Public Administration and Public Services Development Strategy 2014-2020:

Government statute 1007/2013 (I.10.) has reorganized the public administration system concurrent to headcount consolidation. ... Headcount consolidation, however, is only somewhat reflected in the data due to the effects of institutional reorganizations. In general, we may state that the number of employees in the public sector has been nearly constant since 2007. On the whole, public sector employment saw a slight decrease between 2010 and 2011, but by 2014 this tendency appears to be shifting. With respect to the public administration system, having been impacted by consolidation, a significant headcount increase commenced from the beginning of 2011 despite the number of organizations showing a falling trend.... demonstrating the need for additional efforts in the interests of establishing an efficientlyrun state with a lower headcount. Improving both personal development and operating efficiency remains an important challenge. ${ }^{20}$

19 https://www.ksh.hu/docs/hun/xstadat/xstadat_evkozi/e_qli006.html (2016/03/22).

20 http://www.kormany.hu/download/8/42/40000/K\%C3\%B6zigazgat\%C3\%A1s_feljeszt\% C3\%A9si_strat\% C3\%A9gia_pdf (2016/03/22). 
Therefore, reducing the number of public servants and improving the quality of their tasks are related goals, driving greater efficiency. The questions of who should stay and who should move to the private sector naturally arise. Will those less suited for government work exit the public realm while those best suited remain? For the service-oriented state will need to keep those public servants in the system who are most capable of high professionalism, the very people who assumedly will find work with relative ease in the private sector because of their high-level education and competencies. As we shall see, earlier research has already provided evidence in support of this. These are the main issues regarding the personal aspects of cutting bureaucracy, especially when the subject of incentives is broached.

\section{The Possible Reasons and Circumstances for Moving between the Public and Private Sectors}

A study published in $2013^{21}$ analysing out-migration of labour from the public sector makes some important points regarding confirmation bias: For example, compared to the private sector, there is greater stability in the public sector, as the probability of either losing one's job, being moved into another area or taking on a different job is about half as likely compared to the private sector (Elek-Szabó 2013). (On the other hand, there is no significant difference between the two sectors concerning retirement or other types of inactive status.) Therefore, from a job stability point of view, the public sector is considered to be more stable.

Nearly $40 \%$ of respondents felt greater security in the public sector, which could be related to greater stability in the sector's human resources management. Only $20 \%$ of respondents believed the private sector offered greater security. The percentage of the undecided, however, was very high.

But what happened earlier to those forced to leave the public sector? Is the general suspicion true that former public sector employees' chances of finding another job were indeed lower? ${ }^{22}$ Or that former public sector employees had

21 Elek, Péter-Szabó, Péter András: A közszférából történő munkaeró-kiáramlás elemzése Magyarországon. In: Közgazdasági Szemle. LX(May) 2013. pp. 601-602. http://epa.oszk. hu/00000/00017/00203/pdf/EPA00017_kozgazdasagi_szemle_2013_05_601-628.pdf (2016/03/22). The authors of the study analysed the number, composition, final destinations, and future job prospects of those leaving the public sector. The 2013 study used two different databases: the Hungarian Central Statistical Office's labour market survey data pertaining to the 1998 to 2010 period (Hereafter: MEF) and the Central Administration of National Pension Insurance's microlevel panel data on contributions pertaining to the 2000 and 2006 period (Hereafter: ONYF).

22 Elek-Szabó, p. 617. The job placement data are detailed in the study: '...the raw outplacement intensity of public sector leavers (via redundancy) was periodically 25 percent (MEF) or 5 percent (ONYF) lower than that of the private sector although the difference between the two job placement ratios was significant only in the previous case' (p. 614). '...based on the MEF and ONYF data, the possibility of finding work again among the poorly educated (those with a maximum of an $8^{\text {th }}$-grade education or having attended vocational school only) was respectively 
had to accept jobs for which, based on their educational backgrounds, they were overqualified? ${ }^{23}$

\section{In which sector do you feel greater security?}

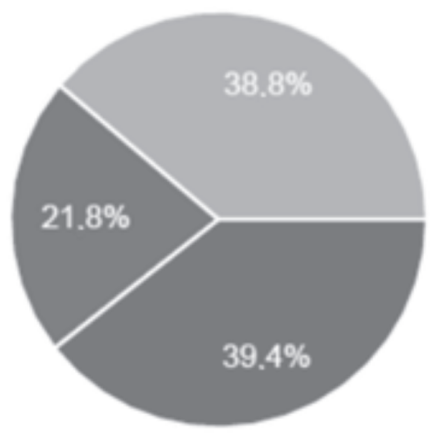

\begin{tabular}{lcc}
\hline Public sector & 141 & $39.4 \%$ \\
\hline Private sector & 78 & $21.8 \%$ \\
\hline Undecided & 139 & $38.8 \%$ \\
\hline
\end{tabular}

Diagram 6. Job stability

Source: Own survey, March 2016

The truth is that earlier analyses do not bear out these suspicions. Based on the estimates of the Jenkins discrete-time risk model, public-sector employees who lost their jobs (irrespective of the reason) took on average 5 to $25 \%$ longer than private sector employees to find another job. At higher levels of educational attainment, the difference disappeared completely. Based on the work of the so-called Logit model, public-sector employees who transitioned to the private sector - irrespective of educational level - did not accept jobs for which they were overqualified in greater numbers than their private-sector counterparts (Elek-Szabó 2013: 602-603).

According to earlier analyses, in most cases, job opportunities and wage differences were the drivers behind migration from the public sector to the private sector. A 2013 study using Hungarian Central Statistical Office data analysed the 1998-2010 period in an attempt to explain headcount fluctuations in the public sector. The study determined that:

20 to 40 percent and 10 to 20 percent lower for those made redundant from the public sector versus their private sector counterparts' (pp. 616-617). 'In summary, therefore, the slightly weaker job placement chances (25 percent worse according to MEF, while not significantly worse according to ONYF) for those made redundant from the public sector can be entirely attributed to the lower possibilities of the poorly educated, ... highly educated/trained publicsector workers have the same job placement chances as their private-sector counterparts, [which] is somewhat at odds with the conventional wisdom...' (p. 617).

23 Ibid.: First of all, we must take into consideration that: 'In summary, 14 percent of public-sector workers and 25 percent of private-sector workers are "overqualified" (p. 623).' '... If we do not look at the raw data pertaining to over-qualification only, but rather take into consideration the component parts that make up the difference between the two sectors, then we will see that there is no difference detected in over-qualification. On this basis, there is no way to support the claim that employees coming from the public sector are accepting "worse" jobs in significantly higher proportion than their private-sector counterparts' (p. 625). 
In the first half of the period (on the basis of Hungarian Central Statistical Office labour survey data), the public-sector workforce grew by approximately eighty thousand people; in the second half of the period, up to 2008, the workforce fell by exactly the same number. Then, between 2009 and 2010, the number began to rise again. Simultaneously, publicsector relative wages also fluctuated significantly. Compared to the wages in the private sector, average public-sector wages (calculated based on statistics provided by the Hungarian Central Statistical Office) were lower at the beginning and end of the period, while in 2003-2004 they were fifteen percent higher (Elek-Szabó 2013: 602).

\section{Migration from the Public Sector to the Private Sector}

On a five-level Likert scale, respondents considered the various incentives to leave the public sector for the private sector and to what extent a given incentive influenced their decision. Respondents' input regarding wages supported the professional literature's earlier findings, which was not necessarily the case regarding job opportunity.

The first question concerned greater pay and benefits; more than $70 \%$ of respondents believed that these determinants greatly influenced the decision to leave the public sector. Remuneration carried much less weight, however, going in the other direction. Only $36 \%$ believed that higher pay and benefits played a great part in the decision to leave the private sector for the public, while $22.1 \%$ claimed that it played no part. This is consistent with the professional literature's earlier findings that when leaving for the private sector the dominant factor for workers was pay and benefits.

Higher salary and benefits [In your experience/opinion, to what extent has this determinant influenced your decision to leave the PUBLIC SECTOR for the PRIVATE SECTOR?]

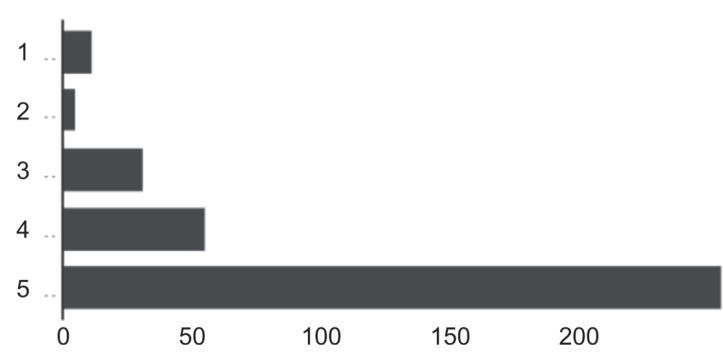

\begin{tabular}{llll}
\hline 1. & Not at all & 11 & $3.1 \%$ \\
\hline 2. & Little & 5 & $1.4 \%$ \\
\hline 3. & Somewhat & 31 & $8.7 \%$ \\
\hline 4. & Much & 55 & $15.4 \%$ \\
\hline 5. & Greatly & 256 & $71.5 \%$ \\
\hline
\end{tabular}

Source: Own survey, March 2016

Diagram 7.1. Higher salary and benefits - from the point of leaving the public sector 
Higher salary and benefits [In your experience/opinion, to what extent has this determinant influenced your decision to leave the PRIVATE SECTOR for the PUBLIC SECTOR?]

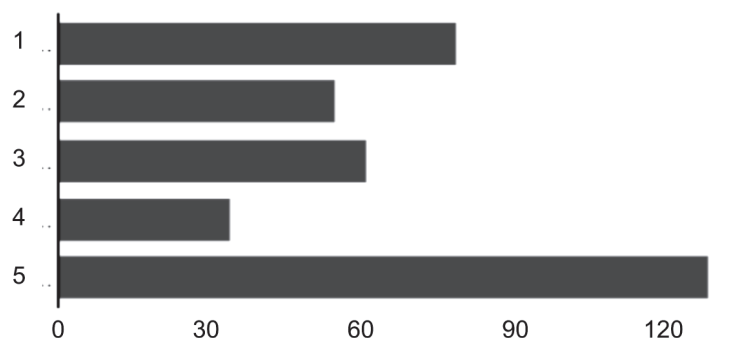

\begin{tabular}{clcc}
\hline 1. & Not at all & 79 & $22.1 \%$ \\
\hline 2. & Little & 55 & $15.4 \%$ \\
\hline 3. & Somewhat & 61 & $17 \%$ \\
\hline 4. & Much & 34 & $9.5 \%$ \\
\hline 5. & Greatly & 129 & $36 \%$ \\
\hline
\end{tabular}

Diagram 7.2. Higher salary and benefits - from the point of leaving the private sector

The second determinant was job opportunity, specifically finding a job related to one's studies or for which one was ideally suited. As for public-sector workers leaving for the private sector, far fewer respondents believed these to be great influences on their decision when compared to salary considerations. Approximately the same number felt likewise among workers leaving the private sector for the public. Thus, we can say that the two main factors making up job opportunity (finding a job related to one's studies or for which one was ideally suited) showed no large variance between directions (going from public to private or vice versa).

Finding a job related to one's studies [In your experience/opinion, to what extent has this determinant influenced your decision to leave the PUBLIC SECTOR for the PRIVATE SECTOR?]

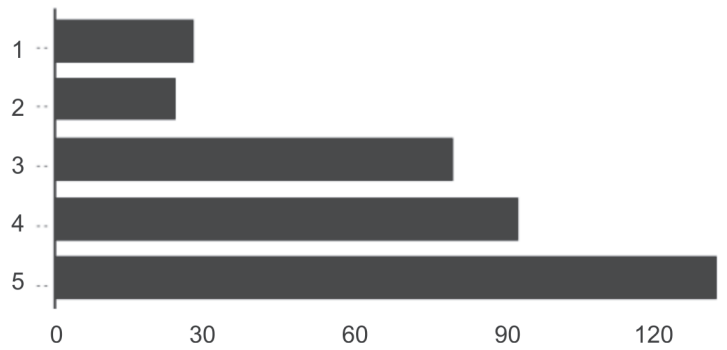

\begin{tabular}{clcc}
\hline 1. & Not at all & 28 & $7.8 \%$ \\
\hline 2. & Little & 24 & $6.7 \%$ \\
\hline 3. & Somewhat & 80 & $22.3 \%$ \\
\hline 4. & Much & 93 & $26 \%$ \\
\hline 5. & Greatly & 133 & $37.2 \%$ \\
\hline
\end{tabular}

Source: Own survey, March 2016

Diagram 7.3. Finding a job related to one's studies - from the point of leaving the public sector 
Job possibilities in line with one's educational attainment [In your experience/ opinion, to what extent has this determinant influenced your decision to leave the PUBLIC SECTOR for the PRIVATE SECTOR?]

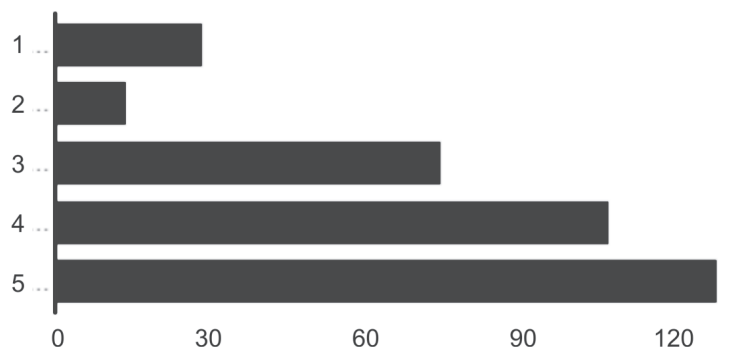

\begin{tabular}{clcc}
\hline 1. & Not at all & 29 & $8.1 \%$ \\
\hline 2. & Little & 14 & $3.9 \%$ \\
\hline 3. & Somewhat & 76 & $21.2 \%$ \\
\hline 4. & Much & 109 & $30.4 \%$ \\
\hline 5. & Greatly & 130 & $36.3 \%$ \\
\hline
\end{tabular}

Source: Own survey, March 2016

Diagram 7.4. Job possibilities in line with one's educational attainmentfrom the point of leaving the public sector

Finding a job related to one's studies [In your experience/opinion, to what extent has this determinant influenced your decision to leave the PRIVATE SECTOR for the PUBLIC SECTOR?]

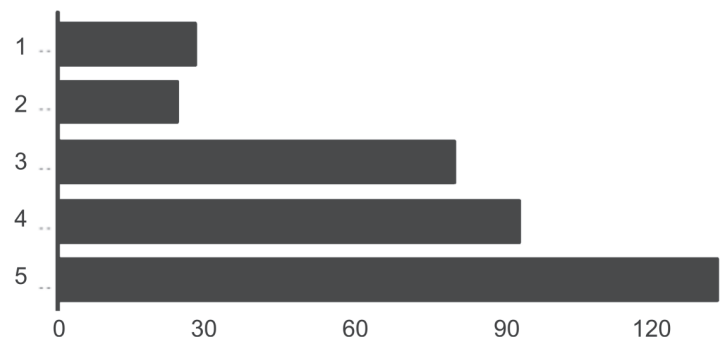

\begin{tabular}{clcc}
\hline 1. & Not at all & 28 & $7.8 \%$ \\
\hline 2. & Little & 24 & $6.7 \%$ \\
\hline 3. & Somewhat & 80 & $22.3 \%$ \\
\hline 4. & Much & 93 & $26 \%$ \\
\hline 5. & Greatly & 133 & $37.2 \%$ \\
\hline
\end{tabular}

Source: Own survey, March 2016

Diagram 7.5. Finding a job related to one's studies - from the point of leaving the private sector 
[In your experience/opinion, to what extent has this determinant influenced your decision to leave the PRIVATE SECTOR for the PUBLIC SECTOR?]

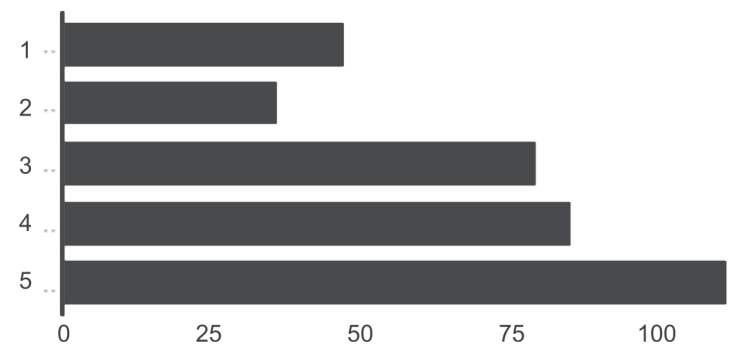

\begin{tabular}{clcc}
\hline 1. & Not at all & 47 & $13.1 \%$ \\
\hline 2. & Little & 36 & $10.1 \%$ \\
\hline 3. & Somewhat & 79 & $22.1 \%$ \\
\hline 4. & Much & 85 & $23.7 \%$ \\
\hline 5. & Greatly & 111 & $31 \%$ \\
\hline
\end{tabular}

Source: Own survey, March 2016

Diagram 7.6. Job possibilities in line with one's educational attainment from the point of leaving the private sector

Some additional conclusions related to the 'quality' of public-sector labour: 'If we can demonstrate that a higher proportion of public-sector employees possesses an educational background that exceeds what their job requires, then this circumstance may hint at a lower-quality labour force when compared to its private-sector counterpart.' Or what we consider to be more likely: 'Those employees who leave view these positions for which they are overqualified as simply a stepping-stone' (Elek-Szabó 2013: 618). The review of job changers further confirmed that those accepting jobs for which they were overqualified were the ones most likely to migrate to the private sector, and that healthcare and social services employees were the least successful in leaving jobs that required higher or secondary educational backgrounds (Elek-Szabó 2013: 621). As per the findings of a 2008 Hungarian National Development Agency investigation, men between the ages of 25 and 34 with two to ten years of public-sector service were the most likely to leave the public sector, which is to say they made up the group of employees least committed to staying (Gellén 2013: 38).

The significant real wage variance that could be found in certain areas between the public and private sectors had the earlier effect of generationally rearranging the labour market. Despite the fluctuations in relative wages, even today the general view remains that public-sector work pays poorly, even though that is not always the case. It is a fact, however, that fresh university and college graduates between 1995 and 2000 (a time of higher education expansion) did not flow into the public sector, but rather the various private-sector areas undergoing a 'youth revitalization'. In these occupations requiring a higher education degree, every age-group saw relatively higher wages (Elek-Szabó 2013: 602). 


\section{Attitudes and Expectations of Employee Groups in the Light of Interoperability}

It is beneficial to review which jobs (that is, which areas) those who leave the public sector are applying for and finding employment in. (We can find discrepancies based on educational attainment.) Public sector specialists (or experts) are finding job opportunities in financial services, law, accounting, sports, and culture. We can see based on these observations that public administration and education have counterparts in the private sector, which are the ones listed above. An individual migrating to the private sector from public administration is twice as likely to work in law or finance. Just as true is the fact that an individual working in education in the public sector is twice as likely to end up in a cultural or sports area in the private sector. The situation, however, is different for public-sector workers with only a secondary school or vocational educational background. They typically find private-sector work in industry (Elek-Szabó 2013: 621-622).

Márton Gellén's comparative study is based on a 2013 empirical study, which looked at mobility from the perspective of individual career planning. Since our study touches upon the findings of his work on several occasions, we find it justified to summarily outline those results now.

The 2013 survey used as its basis a 2008 empirical analysis by the Hungarian National Development Agency which looked at job loyalty in the public sector. As stated above, a non-representative survey completed within the framework of the State Reform Operational Programme showed that the least loyal - and therefore the most likely to leave - group was composed of men between the ages of 25 and 34 with two to ten years of public-sector service. However, many different factors influenced loyalty. For example, loyalty among 'rookie' (first-year) employees was high, but by their second and third year it had dropped to a much lower level. By the time of their tenth year of service, it was hovering around forty percent. The most vulnerable area in terms of crossing over was healthcare, ${ }^{24}$ while geographically it was Hungary's central region. 'The level of loyalty is particularly important when the intention to leave the public sector for the private sector develops' (Gellén, 2013: 38-39). The survey attempted to determine the factors that made up employee empathy and encouraged a worker to stay. Developing a personal relationship with one's supervisor and colleagues was of paramount importance among these considerations. Also important were work environment, the reputation of the company, work-related tasks, work-life balance, recognition, responsibility, and a sense of being influential (Gellén 2013: 39).

Gellén's study also considered generational differences in assessing the issue of mobility by referencing the extensive foreign professional literature, which

24 Authors Elek and Szabó take the opposite view, although the timing of the surveys does not coincide. 
detected Generation Y's susceptibility to postmodern sensibilities in their workplace attitudes and expectations. The so-called 'creative generation' enjoys being part of a decentralized structure, in a motivating environment and a flexible workplace community. Their proactivity towards lifelong learning, openness towards horizontal mobility, and genuine intentions for self-improvement all typify their philosophy. In Hungary, between 2009 and 2012, Generation Y made up a growing portion of public administration staff; thus, from a mobility perspective, it is particularly useful to become acquainted with their workplace expectations (Gellén 2013: 39-40).

The 2013 research made the following observations about employee satisfaction: the lowest levels were found among public-sector employees; in government and municipal offices, satisfaction could be said to be average or mixed; the most satisfied were state-enterprise employees. The overall public-sector sentiment was not good. Negative perceptions were driven by the sector's falling prestige, lower pay, workload, and a sense of being unappreciated. In conjunction with moving to the private sector, small businesses and large non-state corporations were not attractive destinations for public-sector employees (Gellén 2013: 42-44).

The results of the Forsense's representative questionnaire in 2013 revealed that working in the public sector was neither an overly attractive proposition nor particularly irresistible. It is interesting that among the reasons given for working in the public sector were to serve the public interest, 'to help others', and to do work weighted with responsibility. What this means is that in 2013 support for Weber's (classic) Model for Bureaucracy was still very strong, as were the model's cultural roots, which together significantly tamped down desires for migration to the private sector. In 2013, within the public sector, public servants showed the highest likelihood to move to the private sector or possibly abroad to find work (Gellén 2013: 45-47).

One third of the respondents believed that the opportunity to serve the public interest greatly influenced their decision to leave the private sector. Nearly half believed that it greatly or duly ('much') influenced them.

Serving the public interest [In your experience/opinion, to what extent has this determinant influenced your decision to leave the PRIVATE SECTOR for the PUBLIC SECTOR?] 


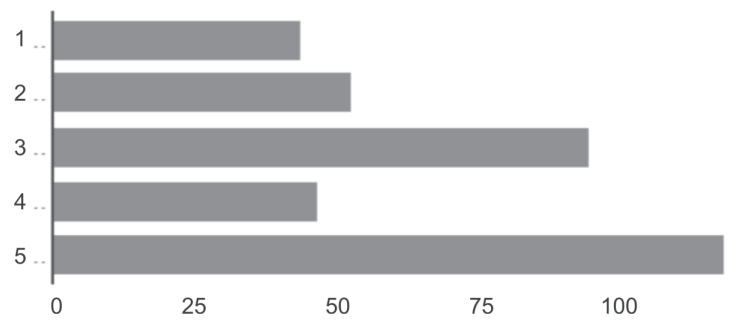

\begin{tabular}{clcc}
\hline 1. & Not at all & 44 & $12.3 \%$ \\
\hline 2. & Little & 53 & $14.8 \%$ \\
\hline 3. & Somewhat & 95 & $26.5 \%$ \\
\hline 4. & Much & 47 & $13.1 \%$ \\
\hline 5. & Greatly & 119 & $33.2 \%$ \\
\hline
\end{tabular}

Source: Own survey, March 2016

Diagram 8. Serving the public interest

Based on all these, we believe it is beneficial to consider which (employee) groups show the highest inclinations for mobility - for leaving the public sector - and what motivations, expectations, and attitudes they harbour, in the light of the educational materials and competency development that adult education can provide.

\section{Useful Knowledge for the Market, the State, and the Individual}

The government expects that for a significant number of public-sector workers migration to the private sector is contingent upon education, retraining, and further education. Providing meaningful knowledge for the employees on the labour market, however, is complicated by several factors. If we wish to forge a synthesis in terms of educational needs and competencies among the state, the economy, and the individual, then we must take into consideration the above aspects. We know:

1. that the scope of employees is complicated by generational considerations;

2. that employees' workplace expectations and demands are diverse due to generational differences;

3. and that employees' assessments of their workplace and their commitment are substantially influenced by generational differences, time of service, and workplace politics and changes therein.

In this ever-changing, multifactorial labour market environment, it is not easy to determine what knowledge will prove useful when a worker is forced to leave the public sector for the private sector. Andragogy often looks to answer the following related questions: Who are the adults returning to the classroom? For what reasons are they doing so? What are they trying to achieve?

With the first question ('Who will go back to school?'), we are already confronted by a belief that many people hold - mainly older generations - that when a person reaches adulthood he is no longer suited for learning. This pessimism towards 
adult learning stubbornly endures despite the origins of adult learning tracing back to the $19^{\text {th }}$ century. Nor have the debates about adult learning over the past several decades focused on the question of whether adults are capable of being taught (which has been settled), but rather on what and how they should be taught!

It is a fact that as a person ages, especially after 25 years of age, his learning capability goes into slow and then faster decline, but at the same time a learning specialization may develop, which is 'the premise that asserts an adult's ability to learn at any given stage of their life depends on the educational contents, forms, and results of their earlier stages of life' (Csoma 2009). Thus, it has a foreseeable influence on the learning method and educational materials the employee will need if further learning or retraining is anticipated for him.

\section{Generations and Learning Methods}

In our research, we found that the blended and frontal methods were the most popular teaching methods. This correlates to the majority of respondents belonging to either Generation Y or the 40-55 age-group, both of which had to some degree spent years living in a digital culture. Correspondingly, they also showed greater receptiveness towards blended learning. The 25 to 55 age-group made up about $60 \%$, while those who deemed blended learning as useful also made up close to $60 \%$. Close to $20 \%$ believed frontal teaching was the most useful, while the older generation (55 and above), which was composed of people who may not be totally at ease living in a digital society, was approximately $30 \%$. E-learning was chosen by $8.1 \%$ of the respondents; among the 16 to 25 age-group, this was $10.3 \%$. There was some overlap between the age-groups and the teaching methods, confirming that adult education methods had to be in harmony with earlier learning experiences.

Which adult education teaching method do you consider as the most useful?

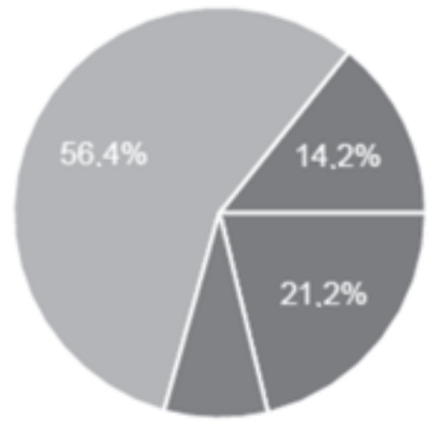

\begin{tabular}{lcc}
\hline $\begin{array}{l}\text { Frontal teaching } \\
\text { (traditional method, based on the } \\
\text { teacher's explaining the material) }\end{array}$ & 76 & $44.1 \%$ \\
\hline E-learning (Internet-based) & 29 & $8.1 \%$ \\
\hline $\begin{array}{l}\text { Blended learning (a combination } \\
\text { of frontal teaching and e-learning) }\end{array}$ & 202 & $56.4 \%$ \\
\hline I do not know & 51 & $14.2 \%$ \\
\hline
\end{tabular}

Diagram 9.1. Education teaching method 


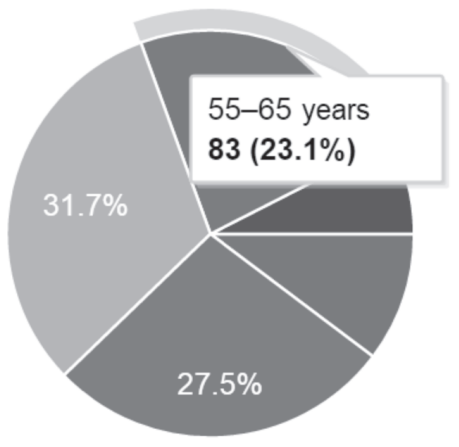

\begin{tabular}{lll}
\hline $16-25$ years old & 37 & $10.3 \%$ \\
\hline $25-40$ years old & 99 & $27.5 \%$ \\
\hline $40-55$ years old & 113 & $31.7 \%$ \\
\hline $55-65$ years old & 83 & $23.1 \%$ \\
\hline$>65$ years old & 27 & $7.5 \%$ \\
\hline
\end{tabular}

Diagram 9.2. Age of respondents

A 2009 State Audit Office of Hungary study determined that jobseekers who could choose for themselves the training that appeared to be the most appropriate for their needs were able to find jobs in greater numbers than those who had participated in training recommended by the employment centre. According to the article, this could be linked to motivation; however, we believe that motivation is only a partial answer. We believe individuals were drawn to those types of training with which they had had previous experience. ${ }^{25}$

Development is influenced by forces affecting personality; therefore, the adult personality must be analysed in a social context. The academic fields of sociology and social psychology offer tremendous assistance in this. Success in adult education is determined by a number of factors, including how much spare time the participant has, the degree to which they are preoccupied or burdened, the lifestyle they lead, and their intentions and motivations. A complicated web of interaction may result, which can be summarized in the following sentence: 'Lifestyle shapes adult education, while adult education shapes lifestyle.' ${ }^{26}$

The most significant influence on the question of what to learn is the demands of the labour market. Our study - among other things - tries to answer the question of whether unemployment can be kept at bay through the opportunities provided via adult retraining and further education. Studies have shown that financial considerations are the main drivers in making the decision to partake in organized adult education. The demand-side dynamics of the labour market prevail on the knowledge market, too, where knowledge becomes a commodity. Accordingly, knowledge market demand may influence personality development by making the knowledge to be acquired either specialized or comprehensive. ${ }^{27}$

The inadequate functioning of markets is often a topic of study in both the economics and public administration fields, and it manifests itself in debates

25 https://www.asz.hu/storage/files/files/Szakmai\%20kutat\%C3\%A1s/2009/t312.pdf (2016/03/22).

26 http://ofi.hu/csoma-gyula-az-andragogiai-elmelet-kialakulasa-es-alapproblemai (2016/03/22).

27 Ibid. 
about public-private interaction. What may be desired by the market and beneficial for the economy, however, may not be good for society. It is important to say a few words about market conditions in the light of the impact that the functioning of the knowledge market has, since the economic impact of human resources is a known fact. Economic growth may be directly impeded by some areas of the economy and certain hierarchical positions if retraining and further education are neglected (via lack of investment) in work that would demand specialization. In contrast, there are areas of the economy and workplace roles that do not require either basic knowledge or expertise. Therefore, the interests of the economy may or may not be in favour of training, but over-qualification in terms of expertise (manifested in the number of degrees an individual has) is in no way beneficial to the economy. ${ }^{28}$

If we analyse the impact education has on unemployment, then we must come to terms with this seemingly contradictory aspect.

Disregarding market rationale, this problem looks different from the state's perspective, for adult education is beneficial to society, helping personal development in adulthood and working against the onset of psychic stasis. The purpose of certain types of remedial training is to effectuate social cohesion rather than economic salvation. In certain cases, economic and social interests conflict with each other. ${ }^{29}$

The third aspect of adult education is personality development/improvement, which is in the interest of the individual, wholly independent of social and economic demands and expectations. Adult education mostly consists of competency development and the expansion of existing knowledge. Learning in adulthood more easily builds upon acquired routine. (Personality improvement, on the other hand, seeks the opposite: for example, stepping outside the bounds of one's comfort zone and letting go of habitual, negative behaviour.) Adult education, therefore, has three main functions, which may come into conflict with each other. If the goal is to reduce drastically the number of workers in the public sector, then the state and the market must work together to define what training the ex-workers will need in order to succeed in their future endeavours.

In our survey, the majority of respondents (58.4\%) would consider further developing their existing knowledge through supplemental training.

Which training method is more effective in helping an employee find a job in either the public sector or the private sector? 


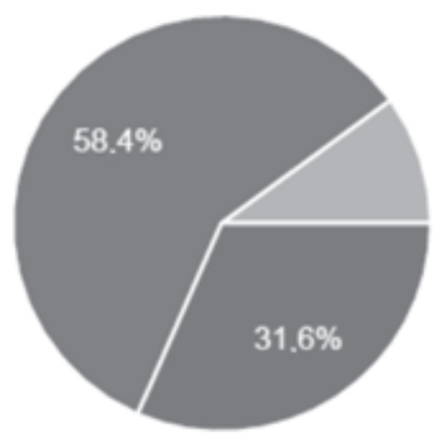

\begin{tabular}{lcc}
\hline $\begin{array}{l}\text { Retraining (learning an entirely } \\
\text { new job/role) }\end{array}$ & 113 & $31.6 \%$ \\
\hline $\begin{array}{l}\text { Supplemental training (expanding } \\
\text { what one already knows about his } \\
\text { profession) }\end{array}$ & 209 & $58.4 \%$ \\
\hline Ido not know & 36 & $10.1 \%$ \\
\hline
\end{tabular}

Source: Own survey, March 2016

Diagram 10. Developing existing knowledge

\section{An Interoperable Assessment of Adult Education - a Survey's Lessons}

The overall experience of conducting a questionnaire survey on interoperabilityincentivizing training among the Hungarian populace was positive. We believe that the government's headcount reduction plan, which is to be packaged together with training to increase the likelihood of finding work, could be successful, assuming the willingness to learn is present, as our survey findings have indicated. We share our findings below.

Nearly $80 \%$ of respondents had participated in some type of adult education and only $5.7 \%$ felt the training had been without merit.

Was participating in adult education useful in helping you accomplish your everyday tasks in either the public sector or the private sector?

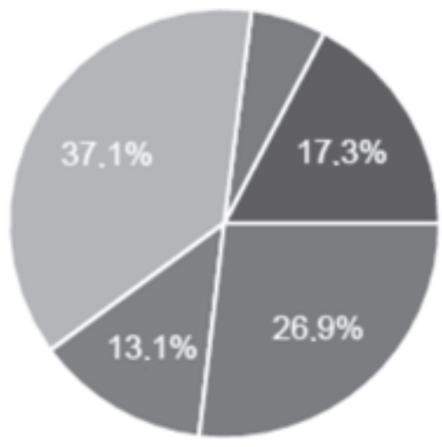

\begin{tabular}{lcc}
\hline $\begin{array}{l}\text { Yes, it was useful in the public } \\
\text { sector. }\end{array}$ & 76 & $26.9 \%$ \\
\hline $\begin{array}{l}\text { Yes, it was useful in the private } \\
\text { sector. }\end{array}$ & 37 & $13.1 \%$ \\
\hline Yes, it was useful in both sectors. & 105 & $37.1 \%$ \\
\hline No, it was not useful. & 16 & $5.7 \%$ \\
\hline Not applicable. & 49 & $17.3 \%$ \\
\hline
\end{tabular}

Diagram 11.1. Participating in adult education 
Nearly $70 \%$ of respondents believed that participating in some type of adult education increased interoperability between the public and private sectors.

Do you believe that adult education for employees increases interoperability between the public and private sectors?

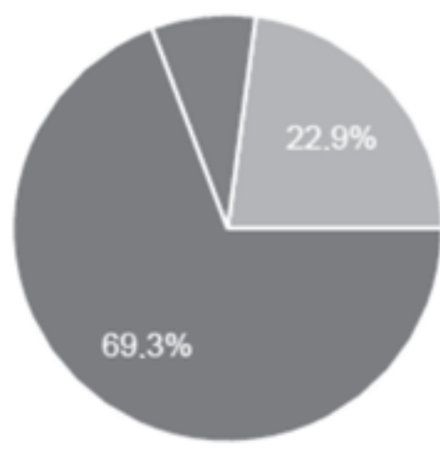

\begin{tabular}{lcc}
\hline Yes. & 248 & $69.3 \%$ \\
\hline No. & 28 & $7.8 \%$ \\
\hline I do not know. & 82 & $22.9 \%$ \\
\hline
\end{tabular}

Diagram 11.2. The role of adult education in interoperability between the public and private sector

An overwhelming majority of respondents would participate in a statesponsored (re)training if it were necessary. In other words, they would accept the state's assistance.

If you were forced to leave the public sector (through redundancy or some other means), would you participate in a state-sponsored retraining course?

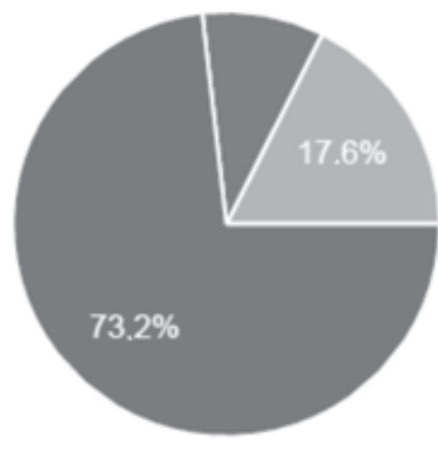

\begin{tabular}{lcc}
\hline Yes. & 262 & $73.2 \%$ \\
\hline No. & 33 & $9.2 \%$ \\
\hline I do not know. & 63 & $17.6 \%$ \\
\hline
\end{tabular}

Diagram 11.3. State-sponsored retraining 


\section{Summary}

The current study aims at analysing the context of the Hungarian government's aspiration to cut bureaucracy and increase public administration's efficiency, thus impacting personnel and reorganizing the labour market. The public-sector headcount reduction is being justified in terms of Hungary's inadequate private-/ public-sector employment ratio. Out of four million employees, approximately one million receive their pay from the state. Despite the fact that the greater the number of workers in the private sector, the greater the amount of tax revenue flowing into the state coffers, the higher the GDP and the better the services provided by the state. To that end, the government would cut the percentage of public-sector employees to $10 \%$ of the total over the course of ten to fifteen years. This reorganization can come to fruition only via the development of intellectual capital and a well-designed system for retraining and further education.

According to the professional literature and the conclusions of various European Union and Hungarian strategic works, knowledge will be the most important renewable resource of the $21^{\text {st }}$ century, and so knowledge itself must come under the microscope. As knowledge (and specifically the flourishing and renewal of tacit knowledge) is a lifelong endeavour, the European Union has proposed and defined key competencies that are essential for success on the labour market and numerous other areas of life. Citizens can benefit by better developing their knowledge and competencies through different types of adult education. But the desire to learn varies by person. Earlier studies have determined that those stuck on the margins of society, in other words, the people who would benefit the most from education, are the ones least open to it.

During the reorganization of Hungarian public administration, we must be cognizant of the fact that it is strongly rooted in Weber's Model for Bureaucracy. With earlier governments attempting to move it in the direction of New Public Management, we have today a mixed crossvergence setting. Today, there is no insurmountable gap between public administration, with its many managerialstyle elements, and the mechanics of the private sector. In our survey, half of the respondents believed that with proper training the disparities between the two sectors could be overcome.

The Hungarian public sector - specifically public administration - saw increases in headcount following the System Changeover, but the government now believes that its extensive size has become detrimental to the sector's efficiency. Bearing that in mind, we have reviewed the earlier experiences of interoperability between the public and private sectors - for the main part our research conforms to professional literature.

Previously, the stability of the public sector versus the private sector was highlighted (the likelihood of unemployment, being moved into another area, or 
taking on a different job was much lower in the public sector). A strong plurality of our respondents $(40 \%)$ also believed that the public sector offered greater security, while only $20 \%$ believed that the private sector did so (in terms of job opportunities, livelihood, etc.).

Previously it had been shown that the chances of finding a new job for someone leaving the public sector were not significantly worse than for their private-sector counterpart (and above a certain educational level, there was no difference at all).

We also knew that migration between the public and private sectors occurred primarily because of job opportunities and wage differences. In our survey, $71.5 \%$ believed that higher compensation and better benefits were a strong catalyst for leaving the public sector, while $15.4 \%$ believed them to be rather strong. Thus, our research has supported our earlier conjecture. Job opportunities as a catalyst were not deemed to be as strong a driver between the private and public sectors.

Commitment to and expectations/demands of the workplace in the public sector are substantially influenced by generational differences, while adult retraining and further education are influenced by a web of complicated reasons behind possible motivations.

In cases of retraining and further education offered by the state, we must be wary of generational differences and possible motivations, while also keeping in mind the influence education can have on the market, society, and the individual. Our research has shown that the demand for a given type of instruction is also influenced by generational differences among those who wish to learn. Overall, our respondents showed an interest in learning.

\section{References}

CSOMA, Gyula. 2009. Az andragógiai elmélet kialakulása és alapproblémái. The Hungarian Institute for Educational Research and Development. http:// ofi.hu/csoma-gyula-az-andragogiai-elmelet-kialakulasa-es-alapproblemai (2016/03/21).

ELEK, Péter-SZABÓ, Péter András. 2013. A közszférából történő munkaerőkiáramlás elemzése Magyarországon. Közgazdasági Szemle LX(May). http://epa.oszk.hu/00000/00017/00203/pdf/EPA00017_kozgazdasagi_ szemle_2013_05_601-628.pdf (2016/03/22).

EUROPE 2020: Europe's Growth Strategy: Growing to a Sustainable and JobRich Future. http://ec.europa.eu/europe2020/pdf/europe_2020_explained.pdf (2013/03/21).

GELLÉN, Márton. 2013. A közszféra és a magánszféra viszonya az egyéni karrierutak tervezésében. Pro Publico Bono 4. http://uni-nke.hu/uploads/ 
media_items/gellen-marton-a-kozszfera-es-a-maganszfera-viszonya-az-egyenikarrierutak-tervezeseben.original.pdf (2016/03/22).

JÁNOSSY, Dániel-KISS Daisy-PULAY, Gyula. 2009. A felnóttképzési rendszerek hatékonysága nemzetközi összehasonlításban. The State Audit Office of Hungary. https://www.asz.hu/storage/files/files/Szakmai\%20 kutat\%C3\%A1s/2009/t312.pdf (2016/03/22).

KÉZDI, Gábor. 1998. Foglalkoztatás és keresetek a közszférában. In: Kolosi, TamásTóth, István György-Vukovich, György (eds), Társadalmi riport. Budapest: TÁRKI. http://www.tarki.hu/adatbank-h/kutjel/pdf/a868.pdf (2016/03/22).

Közigazgatás és közszolgáltatás-fejlesztési stratégia 2014-2020. http:// www.kormany.hu/download/8/42/40000/K\%C3\%B6zigazgat\%C3\%A1s_ feljeszt\%C3\%A9si_strat\%C3\%A9gia_.pdf (2016/03/21).

POÓR, József-KAROLINY, Mártonné-MUSZTINÉ BÁTFAI, Boróka-PÓTÓ, Zsuzsanna-FARKAS, Ferenc. 2014. Emberierőforrás-menedzselési hasonlóságok és különbözőségek a világ Cranet-felméréseiben részt vevő magán- és közszférabeli szervezeteinél. Pro Publico Bono 1. http://uni-nke. $\mathrm{hu} /$ uploads/media_items/emberieroforras-menedzselesi-hasonlosagokes-kulonbozosegek-a-vilag-cranet-felmereseiben-reszt-vevo-magan-eskozszferabeli-szervezeteinel.original.pdf (2016/03/22).

SZABÓNÉ FENYVESI, Éva. 2006. A tudás mint kimeríthetetlen erőforrás. Tudományos Közlemények 14-15. http://epa.oszk.hu/02000/02051/00005/ pdf/EPA02051_Tudomanyos_Kozlemenyek_14_243-250.pdf (2016/03/21).

THE HUNGARIAN CENTRAL STATISTICAL OFFICE: Felnôttoktatás, felnóttképzés, March 2014. https://www.ksh.hu/docs/hun/xftp/stattukor/ felnottoktatas13.pdf (retrieved: 2013/03/21).

THE HUNGARIAN INSTITUTE FOR EDUCATIONAL RESEARCH AND DEVELOPMENT: Az egész életen át tartó tanuláshoz szükséges kulcskompetenciák. http://ofi.hu/tudastar/nemzetkozi-kitekintes/egesz-eletenat-tarto (2013/03/21).

THE LISBON STRATEGY 2000-2010. An Analysis and Evaluation of the Methods Used and Results Achieved. http://www.europarl.europa.eu/ document/activities/cont/201107/20110718ATT24270/20110718ATT24270 EN.pdf (2013/03/21).

XXX Csepreghy: 100-200 ezer közalkalmazottat át lehet terelni a versenyszférába. Mandiner January $5^{\text {th }}, \quad 2016$. http://mandiner.hu/cikk/20160105_ csepreghy_100_200_ezer kozalkalmazottat at_lehet_terelni_a_versenyszferaba (2016/03/22).

XXX Durva közigazgatási átszervezésre készül a kormány. Mandiner January $21^{\text {st }}$, 2016. http://mandiner.hu/cikk/20160121_durva_kozigazgatasi_atszervezesre_ keszul_a_kormany (2016/03/21). 
XXX Hitel a Karrier Hídban. www.vg.hu. January $28^{\text {th }}$, 2016. http://www.vg.hu/ gazdasag/ hitel-a-karrier-hidban-464676 (2016/03/21).

XXX Profession.hu. Elbocsátások ellen tiltakoznak a közszférában. January $11^{\text {th }}$, 2016. https://www.profession.hu/cikk_felmondas/20160111/elbocsatasokellen-tiltakoznak-a-kozszferaban/6166\# (2016/03/22).

\section{Graphs}

SUHAJDA, Zoltán. Több tízezer alkalmazottal többen dolgoznak most a közszférában Magyarországon, mint 2012-ben. Metropol, January 18 ${ }^{\text {th }}, 2016$. (Diagram 5.0). http://www.metropol.hu/itthon/cikk/1405209 (2016/03/23).

The Hungarian Central Statistical Office data on public sector employees (Table $6.0)$.

https://www.ksh.hu/docs/hun/xstadat/xstadat_evkozi/e_qli006.html (2016/03/23). 


\section{APPENDIX}

\section{Source: The Hungarian Institute for Educational Research and Development - Az egész életen át tartó tanuláshoz szükséges kulcskompetenciák}

\section{Table. A Summary of the Key Competencies}

\begin{tabular}{ll}
\hline Competency & Definition \\
\hline $\begin{array}{l}\text { Communication in } \\
\text { the mother tongue }\end{array}$ & $\begin{array}{l}\text { Communication in the mother tongue is the ability to express feelings and facts } \\
\text { in both oral and written form (listening, speaking, reading, and writing) and } \\
\text { to interact linguistically in an appropriate way in a full range of societal and } \\
\text { cultural contexts: in education and training, at work, at home, and in leisure } \\
\text { activities. }\end{array}$ \\
\hline
\end{tabular}

Communication in Communication in foreign languages broadly shares many of the same foreign languages characteristics of communication in the mother tongue: the ability to understand, express, and interpret thoughts, feelings, and facts in both oral and written form (listening, speaking, reading, and writing) in an appropriate range of societal and cultural contexts - in education and training, at work, home, and leisure - according to one's wants or needs. Communication in foreign languages also calls for skills such as mediation and intercultural understanding. An individual's level of proficiency will vary between the four dimensions (listening, speaking, reading, and writing) and between the different languages, and according to that individual's social and cultural background, environment, needs, and/or interests.

\begin{tabular}{ll}
\hline Mathematical & $\begin{array}{l}\text { Mathematical competence includes the ability to add, subtract, multiply, and } \\
\text { competence and } \\
\text { divide numbers, use percentages and fractions, in one's head and/or on paper } \\
\text { in science and }\end{array}$ \\
$\begin{array}{l}\text { in order to solve a range of problems in everyday situations. The emphasis is on } \\
\text { process and activity, as well as knowledge, rather than outcome. Competence }\end{array}$ \\
$\begin{array}{l}\text { in science refers to the ability and willingness to use the body of knowledge } \\
\text { and methodology employed to explain the natural world. Competence in } \\
\text { technology is viewed as the application of that knowledge and methodology in } \\
\text { response to perceived human wants or needs. }\end{array}$ \\
\hline
\end{tabular} Digital competence Digital competence involves the confident and critical use of electronic media for work, leisure, and communication. This competency is related to logical and critical thinking, high-level information management skills and welldeveloped communication skills. Information and communication technology prowess means having basic skills in the use of computers to retrieve, assess, store, produce, present, and exchange information and to communicate and participate in collaborative networks via the Internet.

Learning to learn 'Learning to learn' is the ability to organize and conduct one's own learning, both individually and in groups. This competence includes efficient time management; problem-solving; gaining, processing, and assimilating new knowledge; the ability to use the new knowledge in a variety of contexts - at home, at work, in education, and training. More generally, learning to learn strongly influences to what extent an individual is capable of shaping his career path.

Social and civic Social and civic competences include all those types of behaviours that an competences individual must acquire in order to function effectively and constructively in social life and to resolve conflict where necessary. Social and civic competences are necessary for efficient personal and group interactions and are applicable to both public and personal settings. 


\section{Competency Definition}

Sense of initiative and entrepreneurship

Cultural awareness and expression
The sense of initiative and entrepreneurship has both active and passive components. While, on the one hand, it includes the desire to evoke change, it also means being accepting and supportive of external innovations. An entrepreneurial competency includes an individual's responsibility for their own actions (both positive and negative), the development of a strategic approach, the setting and achieving of goals, and being success-oriented.

Cultural competency includes appreciating the importance of the creative expression of ideas, experiences, and emotions in a range of media including music, performing arts, literature, and the visual arts. 